\title{
Taxonomical and functional diversity of Saprolegniales in Anzali lagoon, Iran
}

\author{
Hossein Masigol · Seyed Akbar Khodaparast • Reza Mostowfizadeh-Ghalamfarsa • \\ Keilor Rojas-Jimenez • Jason Nicholas Woodhouse • Darshan Neubauer • \\ Hans-Peter Grossart
}

Received: 10 September 2019/Accepted: 31 December 2019/Published online: 16 January 2020

(C) The Author(s) 2020

\begin{abstract}
Studies on the diversity, distribution and ecological role of Saprolegniales (Oomycota) in freshwater ecosystems are currently receiving attention due to a greater understanding of their role in carbon cycling in various aquatic ecosystems. In this study, we characterized several Saprolegniales species isolated from Anzali lagoon, Gilan province, Iran, using morphological and molecular methods. Four species of Saprolegnia were identified, including $S$. anisospora and $S$. diclina as first reports for Iran, as well as Achlya strains, which were closely related to $A$.
\end{abstract}

Handling Editor: Télesphore Sime-Ngando.

H. Masigol · S. A. Khodaparast

Department of Plant Protection, Faculty of Agricultural

Sciences, University of Guilan, Rasht, Iran

H. Masigol · J. N. Woodhouse - H.-P. Grossart ( $\square)$ Department of Experimental Limnology, Leibniz-Institute of Freshwater Ecology and Inland Fisheries, Alte Fischerhuette 2, 16775 Stechlin, Germany

e-mail: hgrossart@igb-berlin.de

R. Mostowfizadeh-Ghalamfarsa

Department of Plant Protection, School of Agriculture,

Shiraz University, Shiraz, Iran

K. Rojas-Jimenez

Escuela de Biologia, Universidad de Costa Rica,

San Jose 11501, Costa Rica

D. Neubauer · H.-P. Grossart

Institute of Biochemistry and Biology, University of

Potsdam, Potsdam, Germany bisexualis, A. debaryana and A. intricata. Evaluation of the ligno-, cellulo- and chitinolytic activities was performed using plate assay methods. Most of the Saprolegniales isolates were obtained in autumn, and nearly $50 \%$ of the strains showed chitinolytic and cellulolytic activities. However, only a few Saprolegniales strains showed lignolytic activities. This study has important implications for better understanding the ecological niche of oomycetes, and to differentiate them from morphologically similar, but functionally different aquatic fungi in freshwater ecosystems.

Keywords Achlya Saprolegnia $\cdot$ Aquatic ecosystems · Carbon cycling · Polymer degradation . Saprolegniaceae $\cdot$ Achlyaceae

\section{Introduction}

Saprolegniales, as a monophyletic order, belong to the phylum Oomycota. It includes biflagellate heterotrophic microorganisms that have eucarpic mycelial and coenocytic thalli of unlimited growth. They produce asexual (sporangia) and sexual (gametangia) structures delimited by septa. Saprolegniales are mainly predominantly freshwater saprophytes of plant and animal debris (Beakes and Sekimoto 2009). This order contains three families: Achlyaceae (four genera), Saprolegniaceae (11 genera) and Verrucalvaceae (7 genera) (Beakes et al. 2014; Molloy et al. 
2014; Beakes and Thines 2017; Rocha et al. 2018). Amongst these, Achlya, Brevilegnia, Dictyuchus, Leptolegnia, Plectospira, Saprolegnia and Thraustotheca have been commonly reported to inhabit freshwater ecosystems (Czeczuga et al. 2005; Mousavi et al. 2009; Marano et al. 2011).

Saprolegniales species have been recently receiving increased attention due to their wide distribution, ubiquitous occurrence (Liu and Volz 1976; Kiziewicz and Kurzątkowska 2004; Nascimento et al. 2011), their devastating fish pathogenicity in aquaculture and fish farms and responsibility for massive decline of natural salmonid populations (Griffiths et al. 2003; Van West 2006; Romansic et al. 2009; Van Den Berg et al. 2013). Aside from their pathogenicity, many authors have also investigated relative frequencies of Saprolegniales throughout different seasons in relation to physico-chemical features of the respective freshwater ecosystems (El-Hissy and Khallil 1991; Czeczuga et al. 2003; Paliwal and Sati 2009). Although these oomycetes are generally isolated from plant debris, their involvement in organic matter degradation in freshwater ecosystems remains less clear.

Species identification of Saprolegniales is largely based on morphological features (Coker 1923; Seymour 1970; Johnson et al. 2002). However, this identification is perplexing due to several reasons. First of all, in many cases, morphological and morphometric characters are vague and variable. Secondly, more determinative features such as sexual structures are not always produced in vitro. Also, lack of type species and accurate description make it even harder to define specific species (Sandoval-Sierra et al. 2014, 2015). Recently, sequencing of the ribosomal internal transcribed spacer (ITS) has been applied to create a phylogenetic framework within which to address issues of morphological and taxonomic ambiguity (Steciow et al. 2014). Whether complementary molecular targets, in addition to the de facto ITS region, would improve this approach or are even necessary is still open to debate (Robideau et al. 2011).

In this study, we investigated the diversity and seasonality of various strains of Saprolegniales isolated from Anzali lagoon, Iran. In total, we obtained 511 isolates from three locations during 2017 and studied their seasonality. From these, 23 isolates were randomly selected representing different sampling time points and locations and identified using morphological and phylogenetic analyses. In addition to their taxonomy, we tested the hypothesis raised by Masigol et al. (2019) that fungi and Saprolegniales differ in their affinity for polymeric dissolved organic matter (DOM) and consequently in their involvement in aquatic DOM degradation and cycling. To this, we evaluated the ligno-, cellulo- and chitinolytic activities of the selected strains. Our results have important implications for understanding the different roles of fungi and Saprolegniales in aquatic ecosystems.

\section{Materials and methods}

Sampling site

Anzali lagoon is situated at the Caspian Sea near Bandar-e Anzali, in the northern Iranian province of Gilan. The lagoon divides Bandar-e Anzali into two parts, and is home to both the Selke Wildlife Refuge and the Siahkesheem Marsh. Three sampling sites as representatives of the main habitats in Anzali lagoon were selected: (1) river entrance, (2) shallow water habitat and (3) urban habitat (Fig. 1).

Seasonal distribution of Saprolegniales and isolation

Throughout 2017, 511 Saprolegniales isolates were isolated using the methods described earlier by Coker (1923) and Seymour (1970). In brief, samples of decaying leaves of the dominant local vegetation collected from the three sampling locations were brought to the mycology laboratory of the University of Guilan in separate sterile polyethylene bags. Leaves were cut into approximately ten equal pieces $(0.5 \times 0.5 \mathrm{~cm})$. After washing with distilled water, they were incubated at $20-25{ }^{\circ} \mathrm{C}$ in sterilized plates containing $10 \mathrm{~mL}$ sterile distilled water with 20 sterilized hemp seed halves (Cannabis sativa L.) (Middleton 1943). Temperature and $\mathrm{pH}$ of surface water were continuously recorded immediately after collecting decaying leaves. Three replicates were considered for each location. The average number of colonized hemp seed halves from ten Petri dishes was used to estimate the abundance of Saprolegniales throughout the year. The presence of Saprolegniales was confirmed by observing at least one of the general 


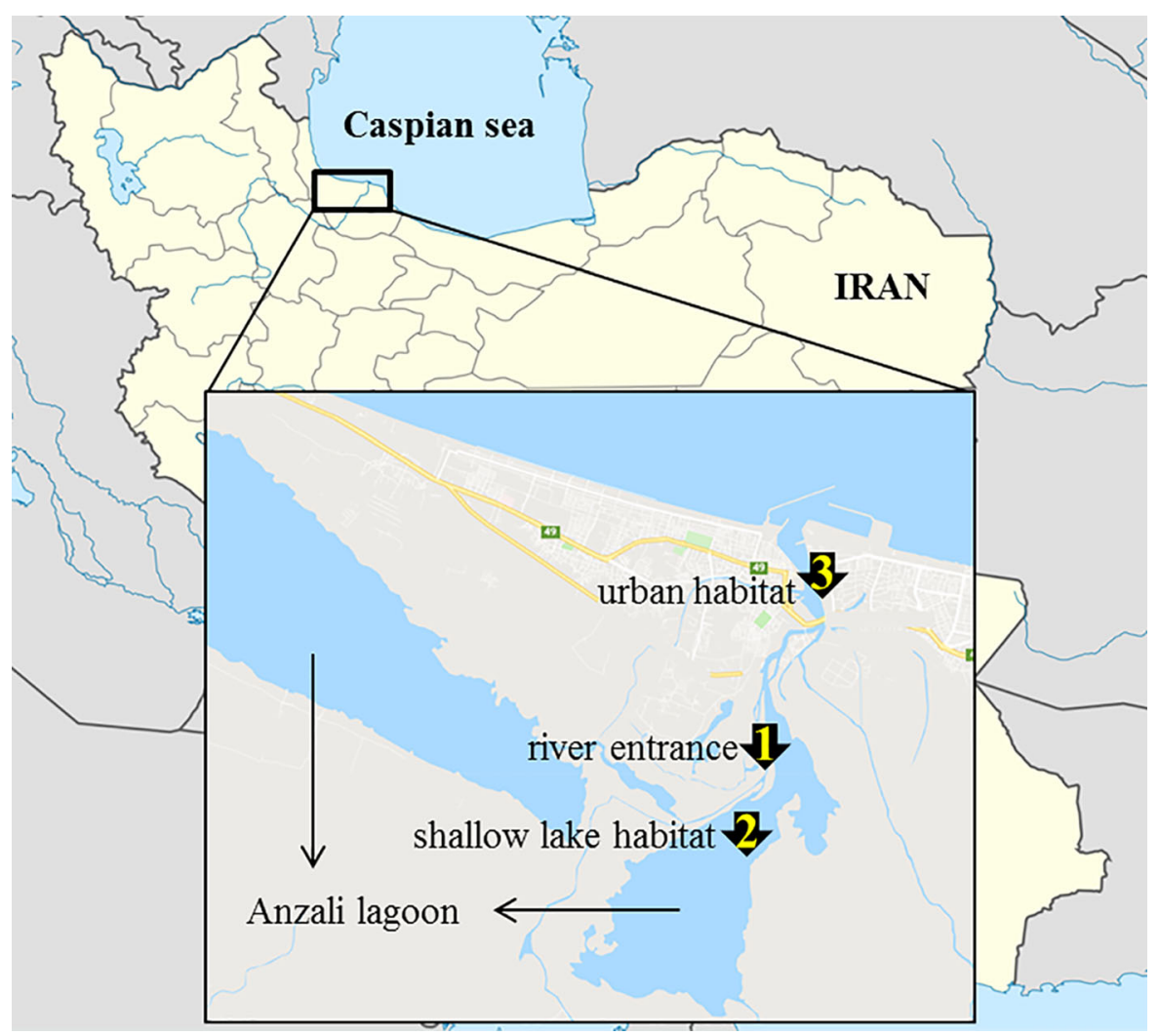

Fig. 1 Sampling locations ((1) river entrance, (2) shallow lake habitat and (3) urban habitat) for isolation of Saprolegniales taxa from Anzali lagoon Iran, during 2017

features of oomycetes such as oogonia, sporangia, large and aseptate mycelia and motile zoospores.

After 3-5 days, a piece of mycelia from the colonized hemp seed halves was transferred to a fresh CMA-PARP medium (Kannwischer and Mitchell 1981). This step was repeated three to five times to achieve bacterial-free (axenic) cultures. A single hypha was transferred to cornmeal agar (CMA) medium (Seymour and Fuller 1987). The hyphal-tip technique was conducted three to five times to obtain a pure culture in CMA. The specimens of these new strains were then deposited in the Fungal Herbarium of the Iranian Research Institute of Plant Protection, Iran.

Identification and phylogenetic analyses

\section{Morphological identification}

Asexual and sexual structures of isolates were characterized and measured in liquid (water) cultures $(n=30)$. To investigate strains failing to produce any sexual structures, several treatments were used. The nutrition treatments included reciprocal culturing of all strains with one another and Trichoderma sp. (Brasier et al. 1978) on CMA, hemp seed agar (HSA) (Hendrix 1964), soybean agar (SA) (Savage et al. 1968), rape seed extract agar (REA) (Satour 1967), carrot juice agar (CJA) (Ershad 1971), mPmTG (Moreau and Moreau 1936a), immersing colonized CMA in glycerine (4\%) (Moreau and Moreau 1936b) and culturing the isolates in Petri dishes containing ten boiled hemp seeds in distilled lake water and distilled water (50/50). The temperature treatments also included culturing the isolates in $5,10,15,20$, and $25{ }^{\circ} \mathrm{C}$ in Petri dishes containing ten boiled hemp seeds in distilled lake water and distilled water (50/50).

\section{DNA extraction and PCR}

The DNA extraction of the isolates was conducted based on a slightly modified protocol of Montero-Pau et al. (2008). Briefly, $100 \mu \mathrm{L}$ of alkaline lysis buffer 
( $25 \mathrm{mM} \mathrm{NaOH}, 0.2 \mathrm{mM}$ disodium EDTA, $\mathrm{pH}$ 8.0) was aliquoted into $1.5-\mathrm{mL}$ tubes. Malt extract broth (MEB) (Galloway and Burgess 1962) was used for the growth of isolates. Mycelial mass was then transferred to the tube and centrifuged for $30 \mathrm{~min}$ at $9000 \mathrm{rpm}$. The tube was incubated at $95{ }^{\circ} \mathrm{C}$ for $30 \mathrm{~min}$ and then cooled on ice for $5 \mathrm{~min}$. Finally, $100 \mu \mathrm{L}$ of neutralizing solution (40 mM Tris- $\mathrm{HCl}, \mathrm{pH}$ 5.0) was added to the tubes. The final solution was vortexed and kept at $-20{ }^{\circ} \mathrm{C}$. Nuclear ITS region was amplified in a Flexible PCR Thermocycler (Analytikjena, Germany) using ITS1/ITS4 primers according to cited amplification conditions (White et al. 1990). The resulting sequences were quality controlled using the Bioedit software (Hall et al. 2011) and submitted to GenBank (National Center for Biotechnology Information; http://www.ncbi.nlm.nih.gov) database.

\section{Phylogenetic analyses}

Sequence alignment was conducted by Clustal X (Thompson et al. 1994) with subsequent visual adjustment. Partition homogeneity tests were conducted on ITS gene alignment by PAUP $* 4.0 \mathrm{a} 136$ (Swofford 2002) using 100 replicates and the heuristic general search option. Aphanomyces stellatus was chosen as an outgroup. Bayesian inference analyses on ITS were carried out with MrBayes 3.1 (Ronquist and Huelsenbeck 2003) in order to reconstruct the phylogenetic trees, imposing a general time-reversible (GTR) substitution model with gamma $(G)$ and proportion of invariable site $(I)$ parameters to accommodate variable rates across sites. We determined the best nucleotide substitution model (Nylander 2004) using MrModelTest 2.3. Two independent runs of Markov chain Monte Carlo (MCMC) using four chains were run over 1,000,000 generations. Trees were saved each 1000 generations, resulting in 10001 trees. Burn-in was set at $5 \%$ generations. Maximum likelihood estimation was carried out using PHYLIP DNAML (Felsenstein 1993) in order to conduct phylogenetic comparison. The robustness of the maximum likelihood trees was estimated by 1000 bootstraps.
Screening for lignolytic, cellulolytic and chitinolytic activities

\section{Lignolytic assay}

Mycelia from the edge of 7-15 days cultures were transferred into 6-well plates containing the cultivation medium proposed by Rojas-Jimenez et al. (2017) and mPmTG agar medium amended with one of the following substrates: $0.1 \% \mathrm{wt} / \mathrm{vol}$ 2,20-Azino-bis 3-ethylbenzothiazoline-6-sulphonic acid diammonium salt (ABTS), 0.02 and $0.005 \% \mathrm{wt} / \mathrm{vol}$ Bromocresol Green (BG), 0.02 and $0.005 \%$ wt/vol Congo Red (CR), 0.02 and $0.005 \%$ wt/vol Phenol Red (PhR), 0.02 and $0.005 \% \mathrm{wt} / \mathrm{vol}$ PolyR-478 (PR) (pH $5+7), 0.02$ and $0.005 \% \mathrm{wt} / \mathrm{vol}$ Remazol Brilliant Blue (RBBR), and 0.02 and $0.005 \% \mathrm{wt} / \mathrm{vol}$ Toluidine Blue (TB) (Pointing 1999; Swamy and Ramsay 1999; Moreira et al. 2000; Novotny et al. 2001; Gill et al. 2002; Rojas-Jimenez et al. 2017). The concentration of different dyes in previous experiments is highly variable. Therefore, two different concentrations were used to ensure that the applied concentration does not impact on the growth or the enzymatic activities of the tested strains. The capacity of each strain to produce lignolytic activity was determined by decolourization of the aforementioned substrates in the area around the mycelia or as a colour change in the media after 3 weeks. We evaluated 1-33, 33-66, and 66-100\% decolourization of the medium in the Petri dishes as weak, medium and strong activities, respectively.

\section{Cellulolytic assay}

The same media as used for evaluation of lignolytic activities were amended with the following enzymatic carbon sources to investigate cellulolytic and pectolytic activities: $7.5 \mathrm{~g}$ carboxymethylcellulose (CMC), $7.5 \mathrm{~g}$ Avicel (AVL) and $5 \mathrm{~g}$ D-cellobiose (DCB) (Wood and Bhat 1988; Pointing 1999; Yoon et al. 2007; Jo et al. 2010). After 3 weeks of incubation, Congo Red $\left(1 \mathrm{mg} \mathrm{mL} \mathrm{mL}^{-1}\right)$ was amended to the medium and incubated at room temperature for 15 min. Subsequently, the medium was rinsed with distilled water, and $30 \mathrm{~mL}$ of $1 \mathrm{M} \mathrm{NaCl}$ added. Degradation of CMC, Avicel and D-cellobiose was confirmed by a transparent appearance of the medium (and mycelia) (Teather and Wood 1982; Pointing 1999). 


\section{Chitinolytic assay}

The method proposed by Agrawal and Kotasthane (2012) was used to evaluate the chitinolytic properties of the strains. Crab shell flakes were ground in a mortar and sieved through the top piece of a $130-\mathrm{mm}$ two-piece polypropylene Buchner filter. Twenty grams of the sieved crab shell flakes was then treated with $150 \mathrm{~mL}$ of $\sim 12 \mathrm{M}$ concentrated $\mathrm{HCl}$ which was added gently and continuously stirred for $45 \mathrm{~min}$ under a chemical fume hood. The final mixture was passed through eight layers of cheese cloth to remove large chitin chunks. The product was treated with two litres of cold distilled water and incubated overnight under static conditions at $4{ }^{\circ} \mathrm{C}$. Sufficient amount of tap water was then passed through the product until the $\mathrm{pH}$ of the product reached 7.0. The final product was squeezed between coffee paper and then sterilized by autoclaving at standard temperature and pressure (STP) (15 psi, $20 \mathrm{~min}, 121^{\circ} \mathrm{C}$ ) (Murthy and Bleakley 2012). The chitinase detection medium consisted of a basal medium comprising (per litre) $0.3 \mathrm{~g}$ of $\mathrm{MgSO}_{4}$ $7 \mathrm{H}_{2} \mathrm{O}, 3.0 \mathrm{~g}$ of $\left(\mathrm{NH}_{4}\right)_{2} \mathrm{SO}_{4}, 2.0 \mathrm{~g}$ of $\mathrm{KH}_{2} \mathrm{PO}_{4}, 1.0 \mathrm{~g}$ of citric acid monohydrate, $15 \mathrm{~g}$ of agar, $200 \mu \mathrm{L}$ of Tween-80, $4.5 \mathrm{~g}$ of colloidal chitin (CC) and $0.15 \mathrm{~g}$ of Bromocresol Purple; the $\mathrm{pH}$ was adjusted to 4.7 , and the neutralized medium autoclaved.

\section{Statistical analyses}

We assessed whether there was a significant impact of month or season broadly on each of the three locations on the frequency of Saprolegniales colonization of hemp leaves, using a two-way ANOVA. The relative contribution of temperature and $\mathrm{pH}$ to any spatiotemporal trends was assessed using Spearman's Rank correlations. A propensity of individual genera or taxa to metabolize individual substrates was assessed using a two-way ANOVA. All statistical analyses were conducted using GraphPad Prism version 8.1 (GraphPad Software, CA, USA).

\section{Results}

Relative abundance of Saprolegniales isolates

From all oomycetes isolated from the three locations sampled along the year, 511 out of $720(\sim 71 \%)$ were assigned to the order Saprolegniales. The relative abundance of Saprolegniales was higher at cold temperatures (autumn, winter and spring seasons) than in summer. The highest temperatures were recorded in 23 July-22 August (in average $\sim 33{ }^{\circ} \mathrm{C}$ ) and the lowest in 21 June-19 February (in average $\sim 3{ }^{\circ} \mathrm{C}$ ). The number of isolates from river entrance, shallow lake and urban habitats was negatively correlated with temperature $\left(R^{2}=0.7233\right.$, 0.5047 and 0.7623 , respectively). However, $\mathrm{pH}$ was constant and no correlation was observed for river entrance, shallow lake and urban habitats ( $R^{2}=2 E-05,0.0037$ and 0.0684 , respectively). Of the 720 hemp seeds, only 209 were not colonized by Saprolegniales isolates $(\sim 29 \%)$. These were either colonized by other microorganisms such as fungi and protists, or remained intact. Co-colonization of Saprolegniales isolates and other unwanted subjects or organisms was not counted as a positive result (Table 1).

Morphological identification

Of the selected isolates, 19 belonged to the genus Saprolegnia (S. anisospora, S. diclina, S. ferax and $S$. parasitica) (Fig. 2a-j, 1-m) and four to the genus Achlya (Fig. 2k, n, o). Four isolates of Achlya failed to produce sexual structures under any circumstances and thus were considered as Achlya spp. Morphologybased taxonomy of Saprolegnia strains was confirmed by phylogenetic analysis of ITS sequences of nrDNA inferred from Bayesian and maximum likelihood methods.

Saprolegnia anisospora (Pringsheim) de BaryBot. Zeitung (Berlin) 41:56. 1883 (Fig. 2a-c)

Mycelium dense; main hyphae branched, hyaline to dark, with 16-46 $\mu \mathrm{m}$ (average $26 \mu \mathrm{m}$ ) width. Sporangia very abundant, mainly fusiform, straight, sometimes curved, renewed in cymose fashion, $80-405 \times 18-50 \mu \mathrm{m}$ (average $220 \times 26 \mu \mathrm{m}$ ). They discharged spores and behaved as saprolegnoids. Cysts $9-13 \mu \mathrm{m}$ in diameter (average $10 \mu \mathrm{m}$ ). Gemmae absent. Oogonia terminal, always spherical, always immature, $78-107 \mu \mathrm{m}$ in diameter. Oogonial wall smooth. Oogonial stalks 1-3 times the diameter of oogonium, slender, slightly irregular and 
Table 1 Number and percentage of colonized hemp seed halves per Petri dish isolated from three sampling sites in Anzali lagoon, Iran throughout 2017

\begin{tabular}{|c|c|c|c|c|c|c|c|c|c|c|c|c|c|}
\hline \multirow[b]{3}{*}{ Seasons } & \multirow[b]{3}{*}{ Months } & \multicolumn{12}{|c|}{ Averaged number of colonized hemp seed halves per Petri dish ${ }^{\mathrm{a}}$} \\
\hline & & \multicolumn{4}{|c|}{ Location 1} & \multicolumn{4}{|c|}{ Location 2} & \multicolumn{4}{|c|}{ Location 3} \\
\hline & & $R 1^{\mathrm{b}}$ & $R 2$ & $R 3$ & $\%$ & $R 1$ & $R 2$ & $R 3$ & $\%$ & $R 1$ & $R 2$ & $R 3$ & $\%$ \\
\hline \multirow[t]{3}{*}{ Spring } & Mar. 21-Apr. 20 & $17^{\mathrm{c}}$ & 18 & 19 & 92.5 & 18 & 17 & 19 & 90.0 & 16 & 17 & 17 & 85.0 \\
\hline & Apr. 21-May 21 & 13 & 13 & 13 & 65.0 & 13 & 13 & 11 & 60.0 & 12 & 13 & 14 & 67.5 \\
\hline & May 22-Jun. 21 & 11 & 12 & 11 & 57.5 & 12 & 12 & 13 & 62.5 & 11 & 10 & 9 & 47.5 \\
\hline \multirow[t]{3}{*}{ Summer } & Jun. 22-Jul. 22 & 10 & 9 & 9 & 45.0 & 13 & 14 & 14 & 70.0 & 13 & 14 & 13 & 67.5 \\
\hline & Jul. 23-Aug. 22 & 5 & 4 & 5 & 22.5 & 4 & 3 & 4 & 17.5 & 5 & 5 & 6 & 27.5 \\
\hline & Aug. 23-Sep. 22 & 9 & 9 & 9 & 45.0 & 12 & 14 & 12 & 65.0 & 13 & 14 & 14 & 70.0 \\
\hline \multirow[t]{3}{*}{ Autumn } & Sep. $23-$ Oct. 22 & 16 & 17 & 17 & 85.0 & 18 & 18 & 17 & 87.5 & 17 & 19 & 18 & 92.5 \\
\hline & Oct. 23-Nov. 21 & 17 & 18 & 17 & 87.5 & 17 & 16 & 16 & 80.0 & 19 & 20 & 20 & 100.0 \\
\hline & Nov. 22-Dec. 21 & 19 & 20 & 20 & 100.0 & 19 & 19 & 20 & 97.5 & 17 & 18 & 19 & 92.5 \\
\hline \multirow[t]{3}{*}{ Winter } & Dec. 22-Jan. 20 & 16 & 15 & 15 & 75.0 & 15 & 14 & 13 & 67.5 & 17 & 19 & 19 & 95.0 \\
\hline & Jan. 21-Feb. 19 & 17 & 17 & 17 & 85.0 & 16 & 16 & 15 & 77.5 & 18 & 17 & 19 & 90.0 \\
\hline & Feb. 20-Mar. 20 & 18 & 19 & 20 & 97.5 & 17 & 17 & 16 & 82.5 & 20 & 19 & 18 & 92.5 \\
\hline
\end{tabular}

${ }^{a}$ Each Petri dish contains 20 hemp seed halves

${ }^{\mathrm{b}}$ Replications

${ }^{\mathrm{c}}$ Averaged number of colonized hemp seed halves from ten Petri dishes

unbranched. Oospores never produced. No specific pattern was observed for any of our strains on CMA.

Material examined Strains MDL5-1 and MDL14-1, on rotten leaves, Anzali lagoon, Anzali, Guilan, Iran, 10-8-2017, H. Masigol; GenBank Acc. No: ITSMK911009 and MK911010.

Saprolegnia diclina Humphrey Trans. Amer. Phil.

Soc. (N.S.) 17:109, pl. 17 (Fig. 2d-f)

Mycelium sparingly to moderately branched, 17-42 $\mu \mathrm{m}$ (average $35 \mu \mathrm{m}$ ) in width. Sporangia abundant, cylindrical, always straight, renewed internally, $120-976 \times 18-69 \mu \mathrm{m}$ (average $460 \times 52 \mu \mathrm{m}$ ). They discharged spores and behaved as saprolegnoids. Cysts $8-11 \mu \mathrm{m}$ in diameter (average $9 \mu \mathrm{m}$ ). Gemmae spherical, 66-110 $\mu \mathrm{m}$ in diameter, terminal, sometimes catenulate. Oogonia terminal, spherical, obpyriform, 75-105 $\mu \mathrm{m}$ in diameter. Oogonial wall smooth. Oogonial stalk 1-3 times the diameter of the oogonium, slender and unbranched. Oospores centric, spherical, 6-26 per oogonium and 14-28 $\mu \mathrm{m}$ in diameter. Antheridia abundant, diclinous and androgynous. No specific pattern observed for any of our isolates on CMA.

Material examined Isolates JSL25-2, FSL9, JSL243, JSW5-1, JSW17 and FSW19, on rotten leaves, Anzali lagoon, Anzali, Guilan, Iran, 10-8-2017, H. Masigol; GenBank Acc. No: ITS-MK911019, MK911018, MK911016, MK911015, MK911014 and MK911013.

Saprolegnia ferax (Grith.) Thuret Ann. Sci. Nat. Bot. 14:229 et spp. pl. 22. 1850 (Fig. 2g-i)

Mycelium dense; main hyphae highly branched, hyaline to dark, 15-62 $\mu \mathrm{m}$ (average $44 \mu \mathrm{m}$ ) in width. Sporangia abundant, cylindrical, rarely fusiform, always straight, renewed sympodially, $60-490 \times 22-78 \mu \mathrm{m}$ (average $352 \times 51 \mu \mathrm{m}$ ). They discharged spores and behaved as saprolegnoids. Cysts $7-11 \mu \mathrm{m}$ in diameter (average $10 \mu \mathrm{m}$ ). Gemmae were overabundant, extremely irregular, terminal and intercalary. Oogonia terminal, sometimes intercalary, spherical, obpyriform, spherical, 76-99 $\mu \mathrm{m}$ in diameter and sometimes with irregular shapes. 


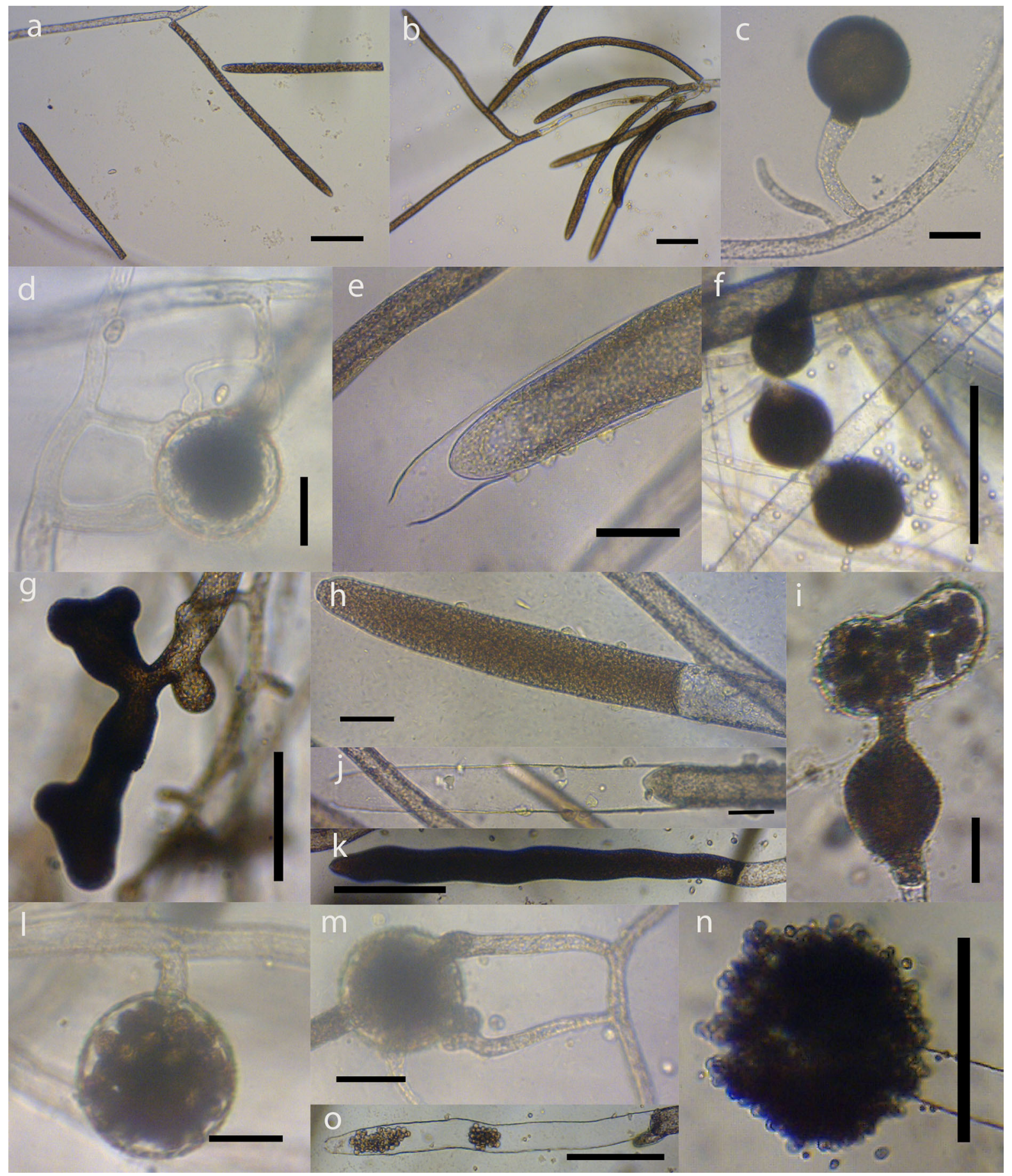

Fig. 2 General morphological characteristics of selected isolates used in this study observed in water culture at room temperature; (a-c) fusiform straight and sporangia (a), cymose fashion renewal of sporangia (b) and terminal immature oogonia with stalk (c) of Saprolegnia anisospora; $(\mathbf{d}-\mathbf{f})$ diclinous and androgynous antheridia (d), internal renewal of sporangia (e) and catenulate spherical gemma (f) of S. diclina; (g-i) an extremely irregular gemma (g), cylindrical sporangia (h) and an oogonium with irregular shape (i) of S. ferax; (j and lm) internal renewal of sporangia (j), lateral oogonia and short stalk (I), diclinous antheridia $(\mathbf{m})$ of $S$. parasitica; $(\mathbf{k})$ sporangia (n), spore clump of Achlya spp. and (o) empty sporangia (bar $=50 \mu \mathrm{m}$, except for $\mathbf{k}, \mathbf{n}$ and $\mathbf{o}$ which are $200 \mu \mathrm{m}$ ) 
Oogonial smooth. Oogonial stalk 1-3 times the oogonium diameter, slender and unbranched. Oospores centric, spherical, 2-48 per oogonium, $15-63 \mu \mathrm{m}$ in diameter. Antheridia very rare, when present diclinous, $1-5$ per oogonia. No specific pattern observed for any of isolates on CMA.

Material examined Isolates JT1L3, JT1W7, JT117, JT1L2, JT1W3-1, JTL6-1 and JT2W6-1, on rotten leaves, Anzali lagoon, Anzali, Guilan, Iran, 10-82017, H. Masigol; GenBank Acc. No: ITSMK911003, MK911002, MK911004, MK911005, MK911006, MK911007 and MK911008.

Saprolegnia parasitica Coker emend. Kanouse, Mycologia 24:447, pls. 13. 1932 (Fig. 2j and l-m)

Mycelium moderately branched, with 18-56 $\mu \mathrm{m}$ (average $39 \mu \mathrm{m}$ ) width. Sporangia cylindrical, renewed internally, $\quad 150-460 \times 20-66 \mu \mathrm{m} \quad$ (average $325 \times 52 \mu \mathrm{m})$. They discharged spores and behaved as saprolegnoids. Cysts 10-12 $\mu \mathrm{m}$ in diameter (average $11 \mu \mathrm{m}$ ). Gemmae absent in water cultures, when present they were terminal, spherical and single. Oogonia mainly lateral, sometimes terminal, $86-110 \mu \mathrm{m}$ in diameter, very rarely catenulate. Oogonial wall smooth. Oogonial stalk very short, 0.4-0.9 times the oogonium diameter, slender, unbranched and sometimes absent. Oospores centric, spherical, 8-32 per oogonium and $12-29 \mu \mathrm{m}$ in diameter. Antheridia diclinous. No specific pattern observed for any of our isolates on CMA.

Material examined Isolates DSL1 and FSL17, on rotten leaves, Anzali lagoon, Anzali, Guilan, Iran, 10-8-2017, H. Masigol; GenBank Acc. No: ITSMK911020 and MK911017.

Phylogenetic analyses

The phylogenetic classification of ITS sequences of Saprolegnia genus inferred from both Bayesian and maximum likelihood methods was consistent with the morphology-based taxonomy. Moreover, we found for most morphological identified species some reliable sequences with high similarity (99-100\%), so that these sequences clustered with our identified species in the same clade (Fig. 3). In addition, O963-13 and O962-13 Achlya strains were closely related with
Fig. 3 Phylogenetic relationships of Saprolegniales from Anzali lagoon, Iran; relationships amongst 34 Achlya (left tree) and 29 Saprolegnia (right tree) taxa based on Bayesian analysis of internal transcribed spacers 1 and 2 and $5.8 \mathrm{~S}$ gene of rDNA sequences. Numbers next to the branches represent posterior probability (left values) based on Bayesian analysis and bootstrap support (right values) based on maximum likelihood analysis

Achlya bisexualis and F962-15 and JT2W9-1 Achlya strains with $A$. intricata and $A$. debaryana.

Screening for lignolytic, cellulolytic and chitinolytic activities

Of all tested isolates, $61 \%$ showed chitinolytic activities. In addition, 52, 43 and $48 \%$ of all tested isolates showed cellulolytic activities in the medium amended with Avicel (AVL), carboxymethylcellulose (CMC) and D-cellobiose (DCB), respectively. In contrast, no significant lignolytic activities were observed. Decolourization of dyes was detected only in the medium amended with Bromocresol Green (BG) and Toluidine Blue (TB) (39 and 8\% of isolates, respectively). In some cases, isolates failed to grow, especially in the medium amended with Phenol Red (phR). Also, in media amended with Congo Red, adsorption by mycelia was observed. Thus, it was not considered as a proof for lignolytic activity (Table 2).

\section{Discussion}

With this study, we sought both to evaluate the spatiotemporal occurrence of Saprolegniales species within the Anzali lagoon and to describe their morphological, phylogenetic and physiological diversity. We were able to confirm the occurrence of four Saprolegnia spp., of which Saprolegnia anisospora and S. diclina have never been reported from Iran. Phylogenetic analysis also suggested that sequences of Achyla spp. were similar to sequences of Achlya bisexualis, $A$. debaryana and A. Achlya intricata. Previously, Dictyuchus Leitgeb and Brevilegnia Coker and Couch genera had been reported from Anzali lagoon (Masigol et al. 2017, 2018).

Generally, we observed a much lower abundance of Saprolegniales isolates in summer, when both precipitation and terrestrial input were lowest. This is in 


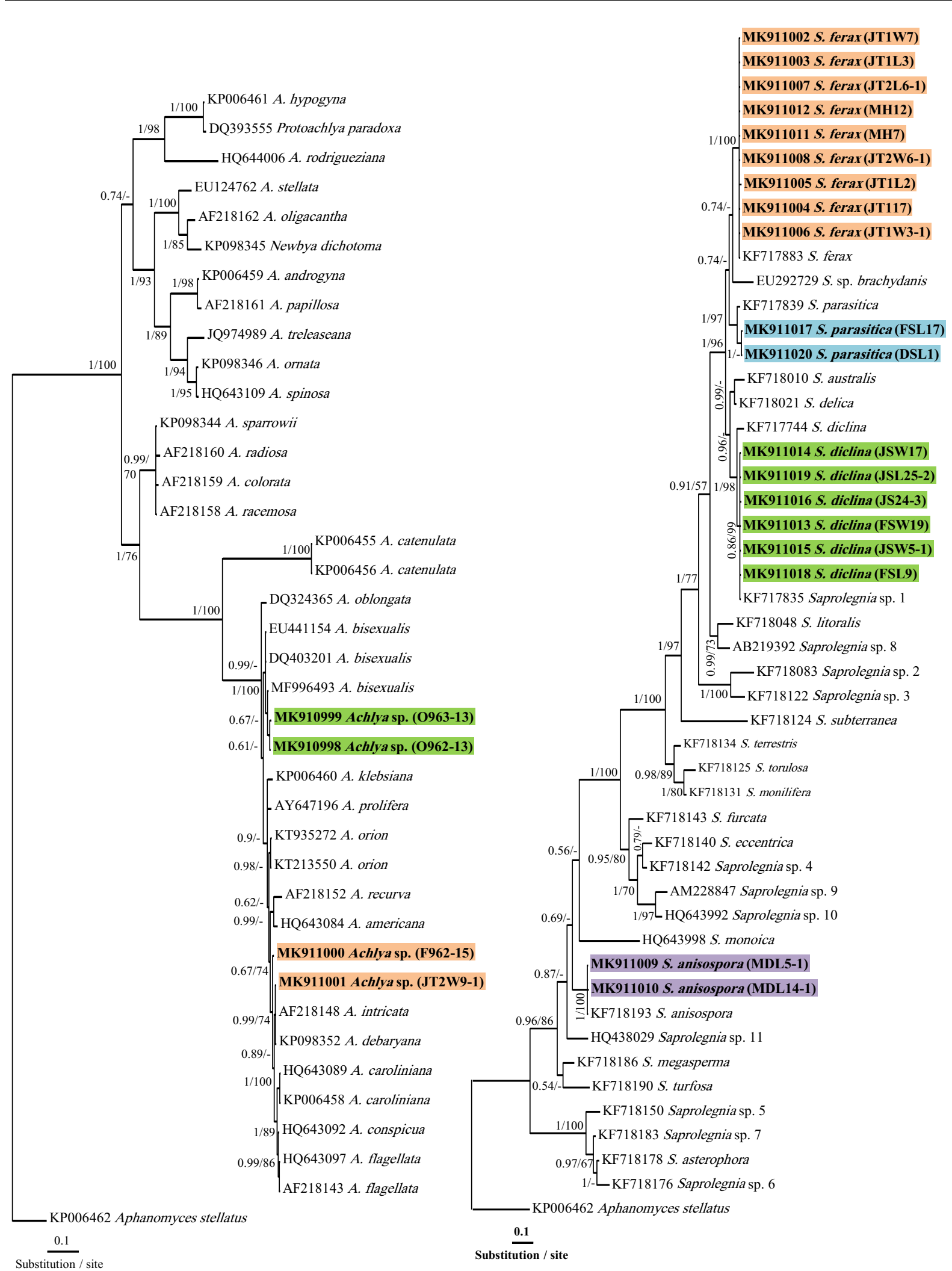


Table 2 Results of experimental screening for lignolytic, cellulolytic and chitinolytic activities of all Saprolegniales isolates isolated from Anzali lagoon, Rasht, Iran

\begin{tabular}{lll}
\hline Isolates & Taxa & AVL $^{\mathrm{a}} \mathrm{CMC}^{\mathrm{a}} \mathrm{DCB}^{\mathrm{a}} \mathrm{ABTS}^{\mathrm{b}} \mathrm{BG}^{\mathrm{b}} \mathrm{CR}^{\mathrm{b}} \mathrm{PhR}^{\mathrm{b}} \mathrm{PR}^{\mathrm{b}} \mathrm{RBBR}^{\mathrm{b}} \mathrm{TB}^{\mathrm{b}} \mathrm{CC}^{\mathrm{c}}$ \\
\hline O962-13 & Achlya sp. \\
O963-13 & Achlya sp. \\
F962-15 & Achlya sp. \\
JT2W9-1 & Achlya sp. \\
MDL5-1 & S. anisospora \\
MDL14-1 & S. anisospora & \\
FSW19 & S. diclina \\
JSW17 & S. diclina \\
JSW5-1 & S. diclina \\
JSL24-3 & S. diclina \\
FSL9 & S. diclina \\
JSL25-2 & S. diclina \\
JT1L2 & S. diclina \\
JT1W3-1 & S. diclina \\
JT1L3 & S. diclina \\
JT1W7 & S. diclina \\
JT117 & S. ferax \\
JT2L6-1 & S. ferax \\
JT2W6-1 & S. ferax \\
MH7 & S. ferax \\
MH12 & S. ferax \\
FSL17 & S. parasitica \\
DSL1 & S. parasitica & \\
\hline
\end{tabular}

White colour $=$ no activity, pale green $=$ weak, green $=$ medium, and dark green $=$ strong activity, red $=$ no growth, pale red $=$ adsorption

${ }^{\mathrm{a}}$ Three carbon sources as indicators of cellulolytic activities, carboxymethylcellulose (CMC), Avicel (AVL), D-cellobiose (DCB), as indicators of Endo-1,4- $\beta$-glucanase, Cellobiohydrolase and $\beta$-Glucosidase

${ }^{\mathrm{b}}$ Dyes as indicators of lignolytic activities, 2,20-Azino-bis 3-ethylbenzothiazoline-6-sulphonic acid diammonium salt (ABTS) (as specific indicator of Laccase activity), Bromocresol Green (BG), Congo Red (CR), Phenol Red (PhR), PolyR-478 (PR), Remazol Brilliant Blue (RBBR) and Toluidine Blue (TB) (as specific indicator of Peroxidase activity)

${ }^{\mathrm{c} C}$ Colloidal chitin (CC) as indicator of chitinolytic activities

agreement with the 25 existing case studies which show a similar pattern and variation in abundance (e.g. Czeczuga et al. 2003; Paliwal and Sati 2009), although this should be considered alongside other potentially covering aspects. For instance, the diversity of Saprolegniales isolates has been correlated with water hardness (Czeczuga et al. 2003) as well as $\mathrm{Mg}^{2+}$, $\mathrm{SO}_{4}{ }^{2-}$ and $\mathrm{Ca}^{2+}$ concentrations (Czeczuga et al. 2002). We should also consider that the highest impact of pollution in Anzali lagoon occurs during the summer season (Fallah and Zamani-Ahmadmahmoodi 2017) associated with a high discharge of agricultural waste and increase in fish breeding activities. Khatib and Khodaparast (2010) noted that the higher water temperature and declining water volume created ideal conditions for bacteria in the summer, which might compete with oomycetes for organic matter.

As our awareness of inland waters increases over time, we are gaining an increased appreciation for their role as key players in the global carbon cycle (Tranvik et al. 2018). Inland waters, through the activity of aquatic bacteria and fungi, are involved in remineralizing large proportions of terrestrial organic matter into greenhouse gases. In this context, understanding the relative contribution of bacteria and fungi, of which fungi are better equipped to break 
down both dissolved and particulate polymeric organic matter, is critical (Grinhut et al. 2011; Zahmatkesh et al. 2016; Collado et al. 2018). However, although aquatic Saprolegniales are generally isolated from floated plant and animal debris, their involvement in organic matter degradation in various freshwater ecosystems has been largely ignored. In their study on seven Saprolegniales isolates from skin of living crayfish, Unestam (1966) showed a lack of cellulolytic activity by Aphanomyces spp., Pythium spp. and Saprolegnia spp.; interestingly, all isolates exhibited chitinolytic activity (Unestam 1966; Nyhlen and Unestam 1975). In contrast, Thompson and Dix (1985) showed moderate-to-strong cellulolytic activity tested in 27 Saprolegniales taxa including Achlya spp. and Saprolegnia spp. Although our strains can fairly represent Achlya and Saprolegnia, isolation of less common genera will be necessary to have a better understanding of their enzymatic affinities.

In this study, none of the isolates showed laccase activity. In addition, no peroxidase activity was observed in more than $60 \%$ of the isolates (Table 2). This agrees with a previous study where the potential for lignin degradation amongst Dictyuchus spp. and Achlya spp. isolates was essentially absent when compared to filamentous fungi isolated from the same environment (Masigol et al. 2019) and elsewhere (Abdel-Raheem and Shearer 2002; Junghanns et al. 2008; Simonis et al. 2008). The lack of any significant lignolytic activity amongst the aquatic Saprolegniales indicates that biopolymer degradation is specific and may be limited to just chitin and cellulose, in contrast to the broader specificity of fungi. Saprophytic Saprolegniales exhibiting chitinolytic and cellulolytic activity, as indicated by our study, may be more critical in the remineralization of chitin-based particulate organic matter. This is supported by a close association of Saprolegniales with crustacean carapaces (Czeczuga et al. 1999, 2002), feathers of wild and domestic bird species (Czeczuga et al. 2004), the benthic amphipod Diporeia spp. (Kiziewicz and Nalepa 2008) and the seeds of plants (Kiziewicz 2005) where chitin comprises a primary component of the biomass. Whilst the presence of an organism possessing chitinolytic enzymes on chitin rich substrates does not immediately prove its involvement in chitin processing, we feel it warrants additional investigation.
In conclusion, it is important to complement traditional morphology-based taxonomy with molecular-based taxonomy but including several markers. It will be also essential to include other techniques such as metabarcoding to have a better impression of the relative abundance of this group with respect to other eukaryotes. To our knowledge, most of the studies performed in various freshwaters lack precise taxonomy and hence are greatly impacting ecological interpretations. We observed clear seasonal dynamics in the occurrence of Saprolegniales in Anzali lagoon with a decline in summer linked to both increased water temperature and high levels of anthropogenic pollution. We confirmed that Saprolegniales isolates lack the broad substrate specificity of fungi, rather exhibiting specific activity towards cellulose or chitinbased substrates. Whether predominantly lignin-based plant-derived substrates are an energy source, or simply a transport vector, for aquatic oomycetes remains unclear and should be further tested. Evaluating the fate of allochthonous carbon in aquatic and global C cycles should better consider the occurrence and impact of oomycetes, particularly for substrates where chitin is particularly dominant. We should better evaluate the interactions between oomycetes and fungi and bacteria both in competition for nutrients and carbon and for potential commensal and synergistic impacts on carbon cycling.

Acknowledgements Open Access funding provided by Projekt DEAL. This work was financed by Caspian Sea Basin Research Center (Number: 2/9077) and Leibniz-Institute of Freshwater Ecology and Inland Fisheries (IGB Berlin), Department of Experimental Limnology and German Academic Exchange Service (DAAD).

Open Access This article is licensed under a Creative Commons Attribution 4.0 International License, which permits use, sharing, adaptation, distribution and reproduction in any medium or format, as long as you give appropriate credit to the original author(s) and the source, provide a link to the Creative Commons licence, and indicate if changes were made. The images or other third party material in this article are included in the article's Creative Commons licence, unless indicated otherwise in a credit line to the material. If material is not included in the article's Creative Commons licence and your intended use is not permitted by statutory regulation or exceeds the permitted use, you will need to obtain permission directly from the copyright holder. To view a copy of this licence, visit http://creativecommons.org/licenses/by/4.0/. 


\section{References}

Abdel-Raheem A, Shearer C (2002) Extracellular enzyme production by freshwater ascomycetes. Fungal Divers 11:1-19

Agrawal T, Kotasthane AS (2012) Chitinolytic assay of indigenous Trichoderma isolates collected from different geographical locations of Chhattisgarh in Central India. SpringerPlus 1(1):73

Beakes GW, Sekimoto S (2009) The evolutionary phylogeny of oomycetes-insights gained from studies of holocarpic parasites of algae and invertebrates. In: Lamour K, Kamoun S (eds) Oomycete genetics and genomics: diversity, interactions, and research tools. Wiley, New York, pp 1-24

Beakes GW, Thines M (2017) Hyphochytriomycota and oomycota. In: Archibald J, Simpson A, Slamovits C (eds) Handbook of the protists. Springer, New York, pp 435-505

Beakes GW, Honda D, Thines M (2014) Systematics of the straminipila: labyrinthulomycota, hyphochytriomycota, and oomycota. In: McLaughlin D, Spatafora J (eds) Systematics and evolution. The mycota (A comprehensive treatise on fungi as experimental systems for basic and applied research), vol 7A. Springer, Berlin, Heidelberg

Brasier CM (1978) Stimulation of oospore formation in Phytophthora by antagonistic species of Trichoderma and its ecological implications. Ann Appl Biol 89(1):135-139

Coker WC (1923) The saprolegniaceae with notes on other water molds. University of North Caroline Press, Chapel Hill, p 201

Collado S, Oulego P, Suárez-Iglesias O, Díaz M (2018) Biodegradation of dissolved humic substances by fungi. Appl Microbiol Biotechnol 102(8):3497-3511

Czeczuga B, Kozlowska M, Godlewska A (1999) Zoosporic fungus species growing on dead benthos crustaceans. Pol J Environ Stud 8(6):377-382

Czeczuga B, Kozłowska M, Godlewska A (2002) Zoosporic aquatic fungi growing on dead specimens of 29 freshwater crustacean species. Limnologica 32(2):180-193

Czeczuga B, Kiziewicz B, Mazalska B (2003) Further studies on aquatic fungi in the River Biebrza within Biebrza National Park. Pol J Environ Stud 12(5):531-543

Czeczuga B, Godlewska A, Kiziewicz B (2004) Aquatic fungi growing on feathers of wild and domestic bird species in limnologically different water bodies. Pol J Environ Stud 13(1):21-31

Czeczuga B, Mazalska B, Godlewska A, Muszyńska E (2005) Aquatic fungi growing on dead fragments of submerged plants. Limnologica 35:283-297

El-Hissy FT, Khallil ARM (1991) Distribution and seasonal occurrence of aquatic Phycomycetes in water and submerged mud in El-Ibrahimia canal (Upper Egypt). J Islam Acad Sci 4(4):311-316

Ershad D (1971) Beitrag zur Kenntnis der Phytophthora-Arten in Iran und ihrer phytopathologischen Bedeutung. Mitteilungen aus der Biologischen Bundesanstalt fur Land-und Forstwirtschaft Berlin-Dahlem 140:60-64

Fallah M, Zamani-Ahmadmahmoodi R (2017) Assessment of water quality in Iran's Anzali Wetland, using qualitative indices from 1985, 2007, and 2014. Wetl Ecol Manag 25(5):597-605
Felsenstein J (1993) PHYLIP (phylogeny inference package). Version 3.5c. Distributed by the author. University of Washington, Department of Genetics, Seattle

Galloway LD, Burgess R (1962) Applied mycology and bacteriology. Loenard Hill, London, pp 54-57

Gill PK, Arora DS, Chander M (2002) Biodecolourization of azo and triphenylmethane dyes by Dichomitus squalens and Phlebia spp. J Ind Microbiol Biotechnol 28(4):201-203

Griffiths R, Robinson J, Jeffries P (2003) Susceptibility of frog (Rana temporaria) and toad (Bufo bufo) eggs to invasion by Saprolegnia. Amphibia-Reptilia 24(3):261-268

Grinhut T, Salame TM, Chen Y, Hadar Y (2011) Involvement of ligninolytic enzymes and Fenton-like reaction in humic acid degradation by Trametes sp. Appl Microbiol Biotechnol 91:1131-1140

Hall T, Biosciences I, Carlsbad C (2011) BioEdit: an important software for molecular biology. GERF Bull Biosci 2(1):60-61

Hendrix JW (1964) Sterol induction of reproduction and stimulation of growth of Pythium and Phytophthora. Science 144(3621):1028-1029

Jo WS, Bae SH, Choi SY, Park SD, Yoo YB, Park SC (2010) Development of detection methods for cellulolytic activity of Auricularia auricula-judae. Mycobiology 38(1):74-77

Johnson TW, Seymour RL, Padgett DE (2002) Biology and systematics of the saprolegniaceae. http://dl.uncw.edu/ digilib/biology/fungi/taxonomy and systematics/padgett book/2002. Accessed 10 Oct 2019

Junghanns C, Krauss G, Schlosser D (2008) Potential of aquatic fungi derived from diverse freshwater environments to decolourise synthetic azo and anthraquinone dyes. Bioresour Technol 99(5):1225-1235

Kannwischer ME, Mitchell DJ (1981) Relationships of number of spores of Phytophthora parasitica var. nicotianae to infection and mortality of tobacco. Phytophthology 71:69-73

Khatib S, Khodaparast H (2010) Survey of Gram-negative bacteria contamination in some parts of Bandar Anzali wetland. J Mar Sci Tech 10(3):57-69

Kiziewicz B (2005) Aquatic fungi growing on seeds of plants in various types of water bodies of Podlasie Province. Pol J Environ Stud 14(1):49-55

Kiziewicz B, Kurzatkowska A (2004) Aquatic fungi and funguslike organisms isolated from surface waters situated near Białystok in Podlasie Province of Poland using the insect Notonecta glauca as bait. Mycol Balc 1(2-3):117-123

Kiziewicz B, Nalepa TF (2008) Some fungi and water molds in waters of lake Michigan with emphasis on those associated with the benthic Amphipod Diporeia spp. J Great Lakes Res 34(4):774-780

Liu C, Volz PA (1976) On the ecology of the Saprolegniaceae. Phtyologia 34(3):209-230

Marano AV, Barrera MD, Steciow MM, Gleason FH, PiresZottarelli CL, Donadelli JL (2011) Diversity of zoosporic true fungi and heterotrophic straminipiles in Las Cañas stream (Buenos Aires, Argentina): assemblages colonizing baits. Fund Appl Limnol Archiv für Hydrobiologie 178(3):203-218

Masigol H, Khodaparast SA, Mostowfizadeh-Ghalamfarsa (2017) The first report of aquatic oomycetes Brevilegnia variabilis, Achlya spp. And Saprolegnia spp. from Anzali 
lagoon in Gilan Provice. In: Proceedings of the 3rd Iranian mycological congress, Sanandaj, p 75

Masigol H, Khodaparast SA, Mostowfizadeh-Ghalamfarsa R, Rojas-Jimenes K, Grossart H-P (2018) Notes on Dictyuchus species (Stramenopila, Oomycetes) from Anzali lagoon, Iran. Mycol Iran 5(2):79-89

Masigol H, Khodaparast SA, Woodhouse JN, Rojas-Jimenes K, Fonvielle J, Rezakhani F, Mostowfizadeh-Ghalamfarsa R, Neubauer D, Goldhammer T, Grossart H-P (2019) The contrasting roles of aquatic fungi and oomycetes in the degradation and transformation of polymeric organic matter. Limnol Oceanogr 64(6):2662-2678

Middleton JT (1943) The taxonomy, host range, and geographical distribution of the genus Pythium. Mem Torrey Bot Club 20:1-171

Molloy DP, Glockling SL, Siegfried CA, Gordon W, Beakes GW, James TY, Mastitsky SE, Wurdak E, Giamberini L, Gaylo MJ, Michael J, Nemeth MJ (2014) Aquastella gen. nov.: a new genus of saprolegniaceous oomycete rotifer parasites related to Aphanomyces, with unique sporangial outgrowths. Fungal Biol 118:544-558

Montero-Pau J, Gómez A, Muñoz J (2008) Application of an inexpensive and high-throughput genomic DNA extraction method for the molecular ecology of zooplanktonic diapausing eggs. Limnol Oceanogr Methods 6(6):218-222

Moreau F, Moreau M (1936a) Action des sucres les Saprolegniees. Comptes rendus hebdomadaires des séances de l'Académie 202:1086-1087

Moreau F, Moreau M (1936b) Action de la glycerine sur les Saprolegniees. Comptes rendus hebdomadaires des séances de l'Académie 202:152-154

Moreira MT, Mielgo I, Feijoo G, Lema JM (2000) Evaluation of different fungal isolates in the decolourisation of synthetic dyes. Biotechnol Lett 22:1499-1503

Mousavi HAE, Soltani M, Khosravi A, Mood SM, Hosseinifard M (2009) Isolation and characterization of Saprolegniaceae from rainbow trout (Oncorhynchus mykiss) eggs in Iran. J Fish Aquat Sci 4(6):330-333

Murthy N, Bleakley B (2012) Simplified method of preparing colloidal chitin used for screening of chitinase-producing microorganisms. Internet J Microbiol 10(2):e2bc3

Nascimento CA, Gomes EPC, Pires-Zottarelli CLA (2011) Occurrence and distribution of zoosporic organisms in water bodies from Brazilian Cerrado. Mycologia 103:261-272

Novotny C, Rawal B, Bhatt M, Patel M, Sasek V, Molitoris HP (2001) Capacity of Irpex lacteus and Pleurotus ostreatus for decolorization of chemically different dyes. J Biotechnol 89:113-122

Nyhlen L, Unestam T (1975) Ultrastructure of the penetration of the crayfish integument by the fungal parasite, Aphanomyces astaci. Oomycetes J Invertebr Pathol 26:353-366

Nylander JAA (2004) MrModeltest v.2.3. Program distributed by the author. Uppsala University, Evolutionary Biology Centre, Uppsala

Paliwal PC, Sati SC (2009) Distribution of aquatic fungi in relation to physicochemical factors of Kosi river in Kumaun Himalaya. Nat Sci 7(3):70-74

Pointing SB (1999) Qualitative methods for the determination of lignocellulolytic enzyme production by tropical fungi. Fungal Divers 2:17-33
Robideau GP, de Cock AW, Coffey MD, Voglmayr H, Brouwer H, Bala K, Chitty DW, Désaulniers N, Eggertson QA, Gachon CM (2011) DNA barcoding of oomycetes with cytochrome c oxidase subunit I and internal transcribed spacer. Mol Ecol Resour 11(6):1002-1011

Rocha SC, Lopez-Lastra CC, Marano AV, de Souza JI, RuedaPáramo ME, Pires-Zottarelli CL (2018) New phylogenetic insights into Saprolegniales (Oomycota, Straminipila) based upon studies of specimens isolated from Brazil and Argentina. Mycol Prog 17(6):691-700

Rojas-Jimenez K, Fonvielle JA, Ma H, Grossart HP (2017) Transformation of humic substances by the freshwater Ascomycete Cladosporium sp. Limnol Oceanogr 62(5):1955-1962

Romansic JM, Diez KA, Higashi EM, Johnson JE, Blaustein AR (2009) Effects of the pathogenic water mold Saprolegnia ferax on survival of amphibian larvae. Dis Aquat Org 83(3):187-193

Ronquist F, Huelsenbeck JP (2003) MrBayes 3: bayesian phylogenetic inference under mixed models. Bioinformatics 12:1572-1574

Sandoval-Sierra JV, Diéguez-Uribeondo J (2015) A comprehensive protocol for improving the description of Saprolegniales (Oomycota): two practical examples (Saprolegnia aenigmatica sp. nov. and Saprolegnia racemosa sp. nov.). PLoS ONE 10(7):e0132999

Sandoval-Sierra JV, Martín MP, Diéguez-Uribeondo J (2014) Species identification in the genus Saprolegnia (Oomycetes): defining DNA-based molecular operational taxonomic units. Fungal Biol 118(7):559-578

Satour MM (1967) Rape seed extract agar: a new medium for production and detection of oospores of heterothallic species of Phytophthora. Mycologia 59(1):161-166

Savage EJ, Clayton CW, Hunter JH, Brenneman JA, Laviola C, Gallegly ME (1968) Homothallism, heterothallism, and interspecific hybridization in the genus. Phytophthora Phytopathol 58(7):1004-1021

Seymour RL (1970) The genus Saprolegnia. Nova Hedwigia 19:1-124

Seymour R, Fuller MS (1987) Collection and isolation of water molds (Saprolegniaceae) from water and soil. In: Fuller MS, Jaworski A (eds) Zoosporic fungi in teaching and research. Southeastern Publishing, Athens, pp 125-127

Simonis JL, Raja HA, Shearer CA (2008) Extracellular enzymes and soft rot decay: are ascomycetes important degraders in fresh water. Fungal Divers 31(1):135-146

Steciow MM, Lara H, Paul C, Pillonel A, Belbahri L (2014) Multiple barcode assessment within the SaprolegniaAchlya clade (Saprolegniales, Oomycota, Straminipila) brings order in a neglected group of pathogens. IMA Fungus 5:439-448

Swamy J, Ramsay JA (1999) Effects of glucose and $\mathrm{NH}_{4}{ }^{+}$ concentrations on sequential dye decoloration by Trametes versicolor. Enzyme Microb Technol 25:278-284

Swofford DL (2002) PAUP*: phylogenetic analysis using parsimony (*and other methods). Sinauer Associates, Sunderland

Teather RM, Wood PJ (1982) Use of Congo red-polysaccharide interactions in enumeration and characterization of cellulolytic bacteria from the bovine rumen. Appl Environ Microbiol 43(4):777-780 
Thompson JD, Higgins DG, Gibson TJ (1994) CLUSTAL W: improving the sensitivity of progressive multiple sequence alignment through sequence weighting, position-specific gap penalties and weight matrix choice. Nucleic Acids Res 22:4673-4680

Thompstone A, Dix NJ (1985) Cellulase activity in the Saprolegniaceae. Trans Br Mycol Soc 85(2):361-366

Tranvik LJ, Cole JJ, Prairie YT (2018) The study of carbon in inland waters-from isolated ecosystems to players in the global carbon cycle. Limnol Oceanogr Lett 3(3):41-48

Unestam T (1966) Chitinolytic, cellulolytic, and pectinolytic activity in vitro of some parasitic and saprophytic oomycctes. Physiol Plant 19(1):15-30

Van Den Berg AH, McLaggan D, Dieguez-Uribeondo J, Van West P (2013) The impact of the water moulds Saprolegnia diclina and Saprolegnia parasitica on natural ecosystems and the aquaculture industry. Fungal Biol Rev 27(2):33-42

Van West P (2006) Saprolegnia parasitica, an oomycete pathogen with a fishy appetite: new challenges for an old problem. Mycologist 20(3):99-104
White TJ, Bruns TD, Lee SB, Taylor JW (1990) Amplification and direct sequencing of fungal ribosomal RNA genes for phylogenetics. In: Innis MA, Gelfand DH, Sininsky JJ, White TJ (eds) PCR protocols: a guide to methods and applications. Academic Press, San Diego, pp 315-322

Wood TM, Bhat KM (1988) Methods for measuring cellulase activities. Methods Enzymol 160:87-112

Yoon JH, Park JE, Suh DY, Hong SB, Ko SJ, Kim SH (2007) Comparison of dyes for easy detection of extracellular cellulases in fungi. Mycobiology 35(1):21-24

Zahmatkesh M, Spanjers HLFM, Toran MJ, Blánquez P, van Lier JB (2016) Bioremoval of humic acid from water by white rot fungi: exploring the removal mechanisms. AMB Express 6(1):11

Publisher's Note Springer Nature remains neutral with regard to jurisdictional claims in published maps and institutional affiliations. 